\title{
Gulf wireworm, Conoderus amplicollis (Gyllenhal) (Insecta: Coleoptera: Elateridae) ${ }^{1}$
}

\author{
Mohammad A. Razzak and Dakshina R. Seal ${ }^{2}$
}

\section{Introduction}

Larvae of click beetles are known as wireworms because of their wire like appearance. The Gulf wireworm, (Gyllenhal) (), is a polyphagous pest mostly found in soil with high organic matter. In the southeastern United States, it is an important pest of sweet potato and can be found in all growing regions irrespective of soil types (Seal et al. 1992c).

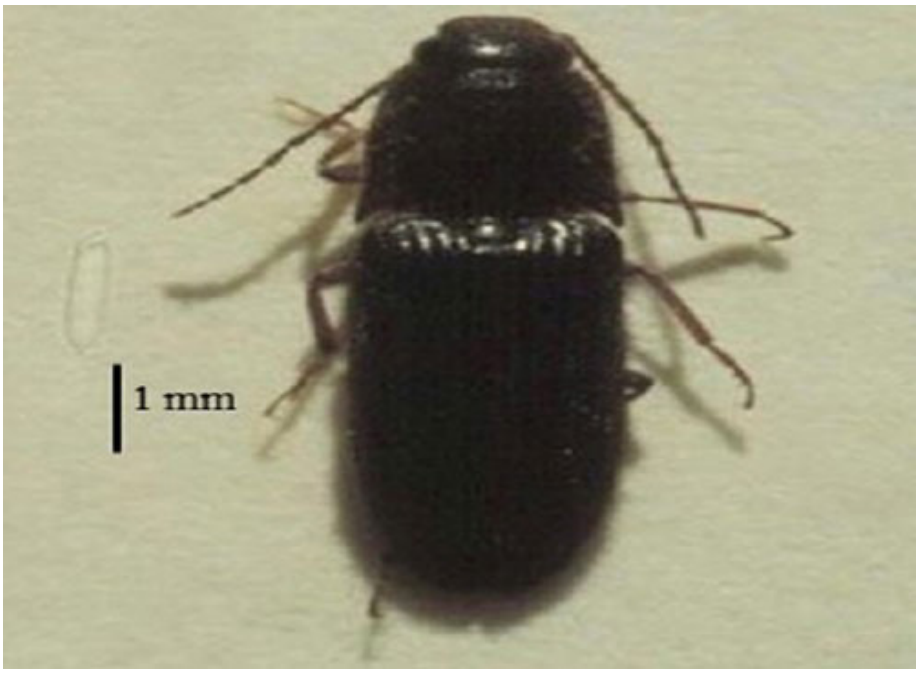

Figure 1. The Gulf wireworm adult, (Gyllenhal).

Credits: Steve L. Brown, University of Georgia. Bugwood.org (Photo ID 5363050).

\section{Distribution}

This species occurs in the southeastern U.S. including Florida, Georgia, Alabama, Louisiana, South Carolina, and North Carolina. It also occurs in California and along the south Atlantic and Gulf Coast from North Carolina to eastern Texas. This insect is also reported to be found in South America, the West Indies, and Asia (Lane 1941, Stone 1975).

\section{Description}

Conoderus amplicollis is a holometabolous insect and its life cycle consists of distinct egg, larva, pupa and adult stages.

Egg: The egg is laid individually or in clusters in moist soil near the soil surface $(<1 \mathrm{~cm})$ adjacent to the food source. White, spherical shaped eggs are smooth in texture and about 0.3 to $0.4 \mathrm{~mm}$ in diameter (Figure 2). The eggs are coated with a glutinous secretion, as a result soil particles stick to the surface which minimizes desiccation (Cockerham and Deen 1936).

Larva: The newly hatched larva is whitish in color, but with the progression of maturity becomes darker to tan or reddish-brown with a hardened and shiny exoskeleton. The number of instars varies from six to eight. Mature larvae measure about $17 \mathrm{~mm}$ long and $2 \mathrm{~mm}$ wide (Figure 2). The body is segmented and divided in to a distinct head, thorax with three pairs of legs, and abdomen with processes

1. This document is EENY713, one of a series of the Entomology and Nematology Department, UF/IFAS Extension. Original publication date October 2018. Visit the EDIS website at https://edis.ifas.ufl.edu for the currently supported version of this publication. This document is also available on the Featured Creatures website at http://entnemdept.ifas.ufl.edu/creatures/.

2. Mohammad A. Razzak; and Dakshina R. Seal, associate scientist, Tropical Research Education Center; UF/IFAS Extension, Gainesville, FL 32611.

The Institute of Food and Agricultural Sciences (IFAS) is an Equal Opportunity Institution authorized to provide research, educational information and other services



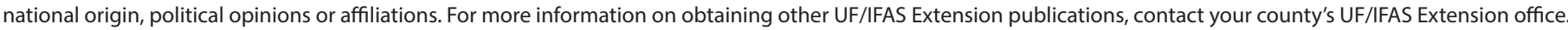
U.S. Department of Agriculture, UF/IFAS Extension Service, University of Florida, IFAS, Florida A \& M University Cooperative Extension Program, and Boards of County Commissioners Cooperating. Nick T. Place, dean for UF/IFAS Extension. 
or prongs at the caudal (rear) end (Cockerham and Deen 1936, Rabb 1963, Seal 1990). Larvae are usually found at a depth 10 to $20 \mathrm{~cm}$ from the soil surface near a food source during cropping season, and inside the smooth walled cell during off season (November to March). Vertical distribution of larvae depends on soil moisture and crop type (Seal 1991). They move to the soil surface only for feeding (Cockerham and Deen 1936).

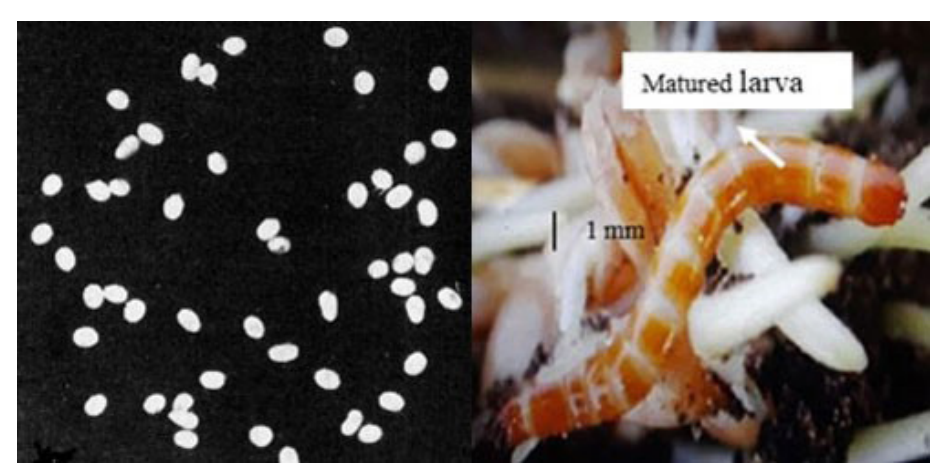

Figure 2. Egg (left) and larval (right) stages of a wireworm. Credits: Eggs photograph by M.C. Lane (1941) (six times natural size) and larval photograph used with permission from the Syngenta Field Protection Guide.

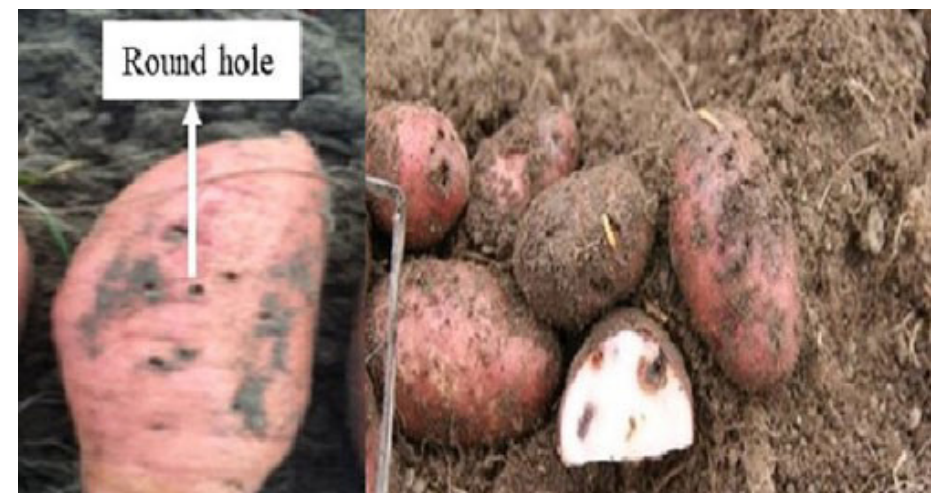

Figure 3. Feeding damage to sweet potato and potato caused by larva of the Gulf wireworm, (Gyllenhal).

Credits: Left photograph by Dakshina R. Seal, UF/IFAS. Right photograph taken from www.mofga.org_compiled by Eric Sideman.

Pupa: After completion of the larval developmental stage they twist and roll in the soil to form a pupal cell within the upper $10 \mathrm{~cm}$ of the soil surface. Pupae are white to yellowish in color. However, head and thorax of pupae tan just prior to the emergence of adult. Pupae greatly resemble the adults except for the elytra, which are reduced in size and twisted ventrally. The size of the pupae is slightly larger than the adults (Cockerham and Deen 1936, Seal 1990, Seal et al. 1992c).

Adult: Adults are usually elongate and hard shelled and are 8 to $9 \mathrm{~mm}$ long and $2 \mathrm{~mm}$ wide (Figure 1). They are dark brown with yellowish legs and antennae (Cockerham and Deen 1936, Stone 1980). The adults are nocturnal and are found hiding under organic material during the day. Generally, they become abundant when sweet potato is grown after sweet corn and distributed randomly in the field (Seal 1990, Seal et al. 1992c).

\section{Life Cycle and Biology}

Overwintering adults mate above ground after a short flight in mid-April to early June and start laying eggs within 12 to 30 days. Average embryonic development stage is about 8 to 20 days at 23 to $25^{\circ} \mathrm{C}$ and 7 to 9 days at 27 to $30^{\circ} \mathrm{C}$. Larval development time in the early spring and early summer is typically with a range of three to four months. However, most larvae developing in August, September and October, overwinter in the 4th to 5th instar and do not pupate until the following spring. Thus, overwintering larval development time is from 200 to over 300 days (Crokerham and Deen 1936, Stone 1980). Overwintered larvae pupate between March and May, pupation lasts about two to four weeks depending on the ambient temperature. At 15 to $25^{\circ} \mathrm{C}$, average pupal duration is 14.3 days (Stone 1980). Afterwards, adults emerge in the late spring through summer and undergo diapause to start a new cycle in late spring. Therefore, has one generation annually (Cockerham and Deen 1936). Seal (1990) reported that, total life cycle may extend up to two to three years in ambient laboratory conditions.

\section{Identifying Characteristics of Mature Larva}

Wireworms are commonly identified based on the larval characteristics. Adult morphological features are not as distinct as those of the larvae because of their hard body surface. The following body sutures and structures are used to distinguish larvae of (Rabb 1963, Seal 1990).

Frons(f): The frons is rectangular and contains two sets of one and two setae (hair like structure), respectively. A seta at the posterior margin of occipital suture (furrow) (pos), a couple of sets of setae in the gena (gn) (part of head) and one set in the post gena (pgn) (Figure 4).

Nasale (n): The nasale consists of three teeth almost equal in size. Between each of the teeth are two setae (Figure 4).

Antenna (ant): The antennae are three segmented and consist of one seta at the basal segment and six setae at the second segment. An elliptical papilla or nipple like elevation (pa) also appears at the tip of the second segment. 


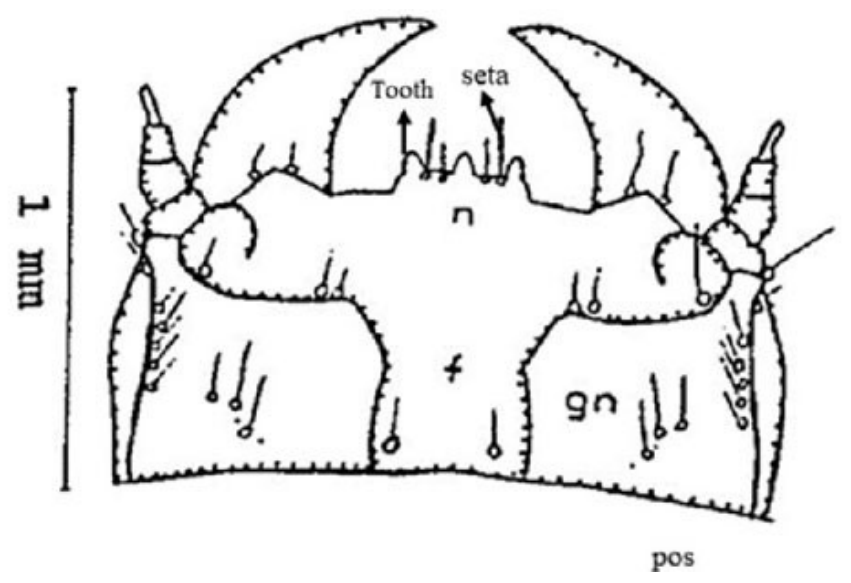

Figure 4. Head (dorsal view) of the larval stages of a Gulf wireworm, (Gyllenhal) showing frons (f), post occipital suture (pos), gena (gn), and nasale $(\mathrm{n})$.

Credits: Dakshina R. Seal, UF/IFAS.

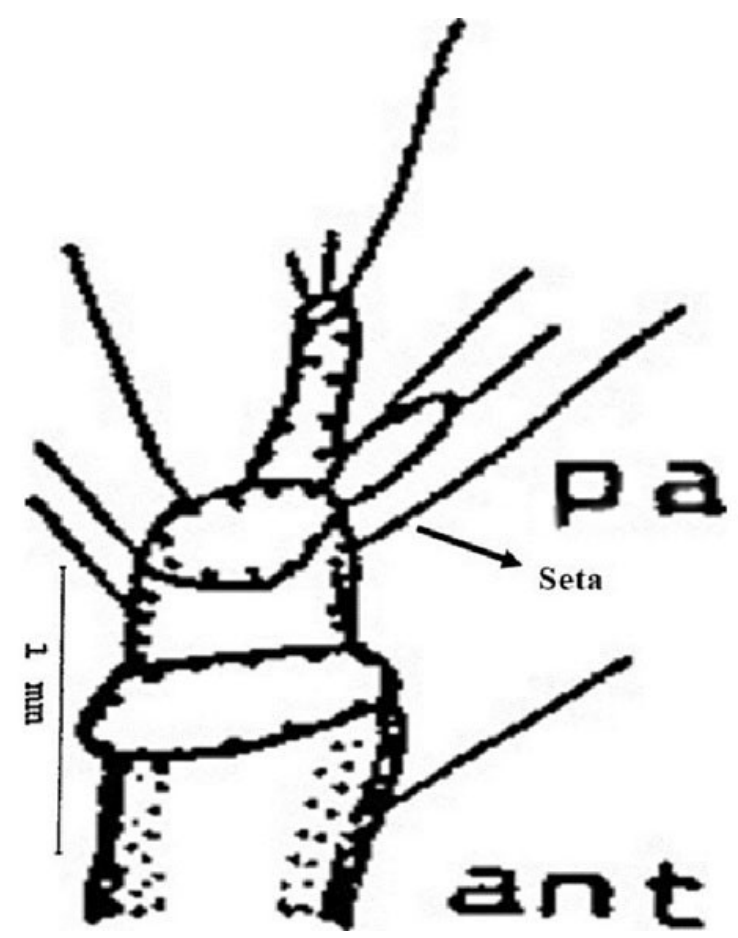

Figure 5. Antenna of the larva of a Gulf wireworm, (Gyllenhal) showing papilla ( $\mathrm{p})$, and seta.

Credits: Dakshina R. Seal, UF/IFAS.

Three setae are present at the tip of the third segment, one of which is longer than the other two (Figure 5).

Mandible (jaw): The mandible is adentate (without teeth), and consists of two setae that are visible dorsally (mdd). Ventrally (mdv) the mandible bears a conspicuous ridge followed by a furrow that can be seen along the entire length (Figure 6).


Figure 6. Mandible of the larva of a Gulf wireworm, (Gyllenhal) showing middorsal (mdd), and midventral (mdv) parts. Credits: Dakshina R. Seal, UF/IFAS.

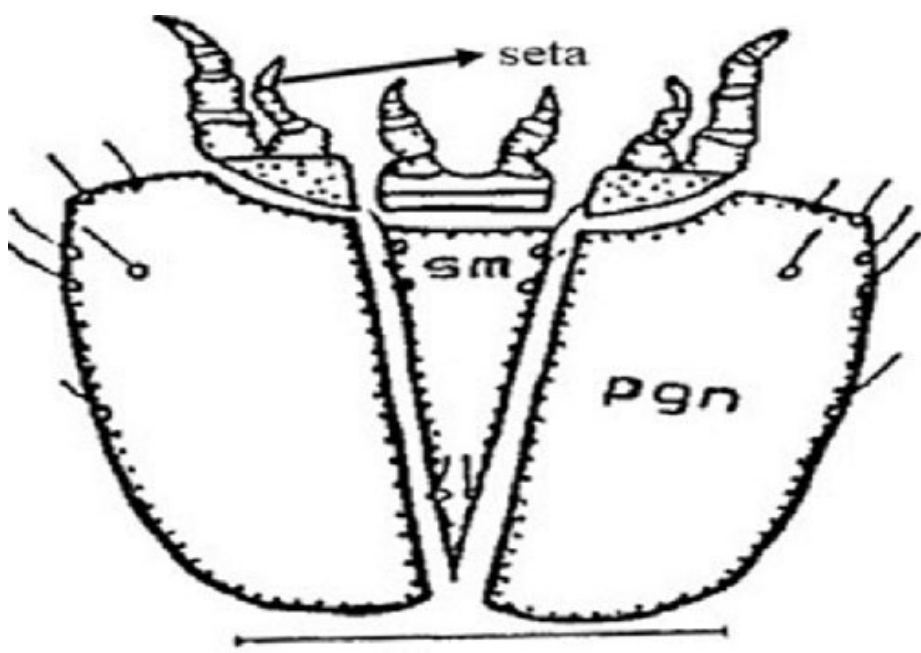

$1 \mathrm{~mm}$

Figure 7. Sub-mentum (sm) of the larva of a Gulf wireworm, (Gyllenhal) showing post genal (pgn) plate and setae. Credits: Dakshina R. Seal, UF/IFAS.

Sub-mentum (sm) (part of lower lip): The sub-mentum consists of six setae. The post genal (pgn) plate contains five setae anteriorly and one seta near the middle (Figure 7).

Pronotum: With several sets of setae, the pronotum (the dorsal part of the first segment behind the head) is marked by the presence of several bright spots, crescentic mark (crm) (Figure 8).

First abdominal tergite (tr) or dorsal part of the abdominal segment: Three setae are present near the anterior margin on each side of the first abdominal tergite. One seta is present near the latero-median position. Two sets of setae are present near the posterior margin on each side of the first abdominal tergite (Figure 9). 


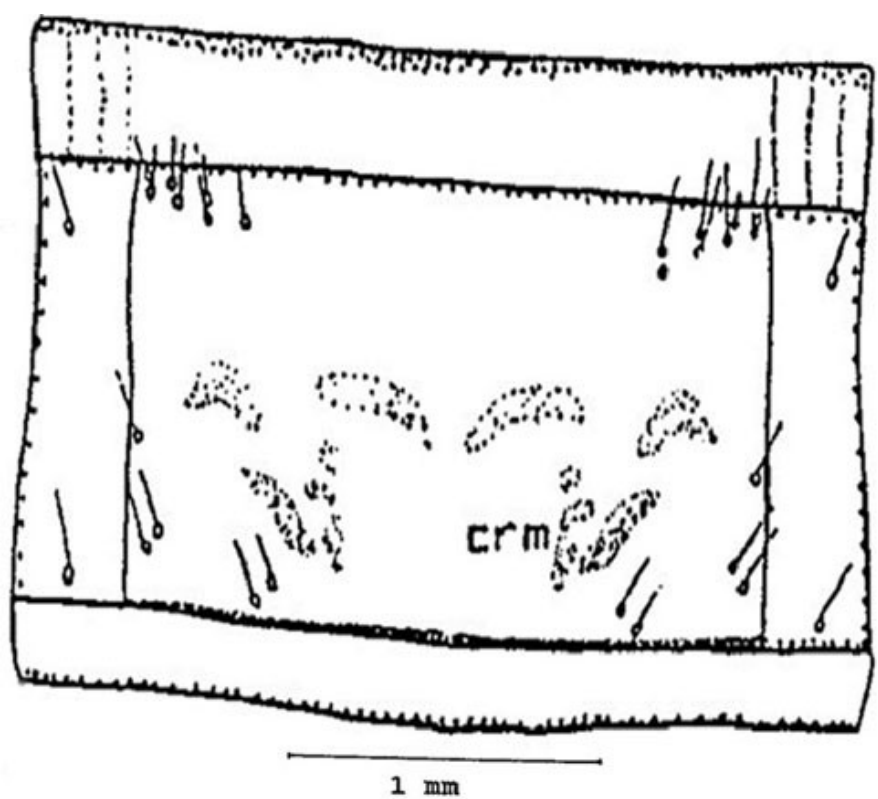

Figure 8. Pronotum of the larva of a Gulf wireworm, (Gyllenhal) showing crescentic mark (crm) and setae.

Credits: Dakshina R. Seal, UF/IFAS.

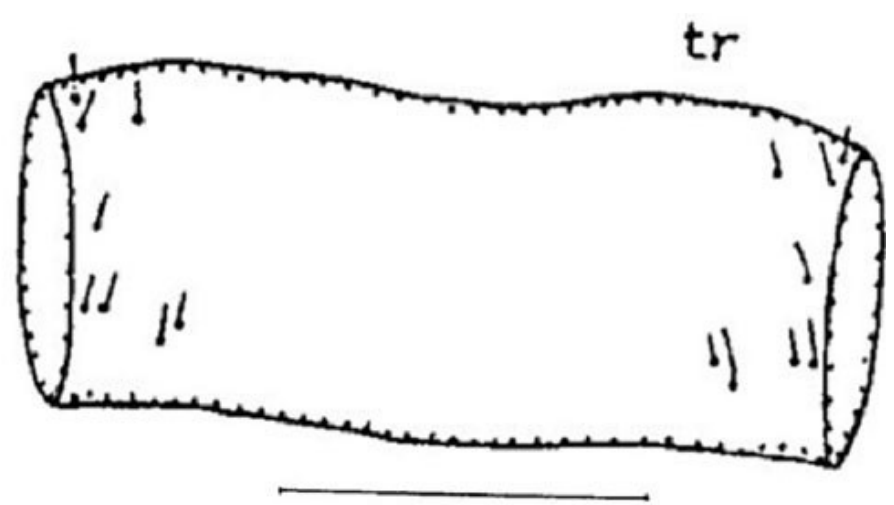

$1 \mathrm{~mm}$

Figure 9. First abdominal tergite (tr) of the larva of a Gulf wireworm, (Gyllenhal).

Credits: Dakshina R. Seal, UF/IFAS.

Ninth abdominal segment: On the dorsal surface you can find one pair of setae anterior to the $\mathrm{V}$ shaped caudal (tail) notch (cn). The urogomphi (ur) is biramous (two branches), you will note that the exterior branch is longer than the interior. Internal branches of the two sides form an open and shallow $\mathrm{V}$ shape which is different in shape from all other species of. On each lateral margin there are six distinct protuberances (pro) (Figure 10).

On the ventral surface are the pseudopods or false legs (pd), they are visible on the ventral side and the tip is eversible. Two prominent ridges are located near the tip of the pseudopod, one on each side (Figure 11).



Figure 10. Ninth abdominal segment (dorsal surface) of the larva of a Gulf wireworm, (Gyllenhal) showing protuberance (pro), caudal notch (cn), urogomphi (ur).

Credits: Dakshina R. Seal, UF/IFAS.



Figure 11. Ninth abdominal segment (ventral surface) of the larva of a Gulf wireworm, (Gyllenhal) showing pseudopod (pd) and tubercles (tu).

Credits: Dakshina R. Seal, UF/IFAS. 


\section{Hosts}

Gulf wireworm has a wide host range. They mainly live below ground, and feed on portions of various root and tuber crops and grain seeds including sweet corn, sweet potato, potato, peanut, carrot, beet, sugarcane, bean, wheat, sorghum, and various weeds. However, sweet potato and potato are the most commonly attacked crops (Day et al. 1971, Hall 1988, Chalfant et al.1990).

\section{Economic Importance}

Conoderus amplicollis is an economic pest of various crops. This pest feeds on germinating seeds, roots, and on potato and sweet potato tubers, as well as other underground parts of their host plant (Jansson and Seal 1994). The adults do little or no damage, the larval stage is the most destructive stage (Andrews et al. 2008). Crops like potato, sweet potato and carrots are damaged from larval tunneling, which lowers the marketable yield (Griffin and Eden 1953) (). Because of root damage, young seedlings can be weakened or eventually die (Seal 1990).

\section{Management}

Waterlogging for at least 8 to 12 hours suffocates both adults and larvae. Cultivation of fields repeatedly at 4 to 8 inches deep exposes wireworm to sunlight and predators, especially birds. Eggs and first instars are vulnerable to desiccation when exposed to sunlight and dry soil. In addition, keeping a field fallow for at least one year with proper sanitation helps to reduce previous years' populations. Crop rotation and planting cover crops that are not a larval food source causes a discontinuation of the life cycle and prevents the influx of a new population. In potato crops, soil amendments, employing different planting and harvest dates, and trap cropping is also reported to manage wireworms (Andrews et al. 2008, Landl and Glauninger 2011).

Entomopathogenic nematodes belonging to the families Steinernematidae and Heterorhabditidae are reported to attack wireworms, though the studies on their effectiveness is underway. For management of wireworms using fungal pathogens in spring wheat, F52, GHA, and DWR 346 is found effective when applied as granules in furrows or as soil drenches compared to seed-coating against and (Reddy et al. 2014) and combination of and azadirachtin and a combination of F52 with seed treatment is reported to protect spring wheat plants and hence enabled higher yield in north central Montana (Antwi et al. 2017). The attract and kill strategy is also being used in potato crops by applying baker's yeast in rows along with (Brandl et al. 2017). Baited traps and sticky traps help to suppress population at a certain level. Some insecticides are effective in controlling wireworms when applied in soil and with seed treatment (Seal et al. 1992a, Seal et al. 1992b).

\section{Selected References}

Andrews N, Ambrosino M, Fisher G, Rondon SI. 2008. Wireworm biology and nonchemical management in potatoes in the Pacific Northwest. Bulletin PNW 607 Oregon State University, Extension and Station Communications. $19 \mathrm{p}$.

Antwi FB, Shrestha G, Reddy GVP, Jaronski ST. 2018. Entomopathogens in conjunction with imidacloprid could be used to manage wireworms (Coleoptera: Elateridae) on spring wheat. Canadian Entomologist 150: 124-139.

Brandl MA, Schumann M, Przyklenk M, Patel A, Vidal S. 2017. Wireworm damage reduction in potatoes with an attract-and-kill strategy using Journal of Pest Science 90: 479-493.

Chalfant RB, Jansson RK, Seal DR, Schalk JM. 1990. Ecology and management of sweet potato insects. Annual Review of Entomology 35: 157-180.

Cockerham KL, Deen OT. 1936. Notes on life history, habits and distribution of (Guér). Journal of Economic Entomology 29: 288-296.

Day A, Cuthbert Jr FP, Reid Jr WJ. 1971. The southern potato wireworm, its biology and economic importance in coastal South Carolina. USDA Technical Bulletin 1443: $1-33$.

Griffin JA, Eden WG. 1953. Control of the Gulf wireworm in sweet potatoes in Alabama. Journal of Economic Entomology 46: 948-951.

Hall D. 1988. Insects and mites associated with sugarcane in Florida. Florida Entomologist 71: 130-150.

Jansson RK, Seal DR. 1994. Biology and management wireworm on potato. Proceedings of the international conference on 'Advances in potato pest biology and management', Jackson Hole, Wyoming, October 1991: 31-53.

Landl M, Glauninger J. 2011. Preliminary investigations into the use of trap crops to control spp. (Coleoptera: Elateridae) in potato crops. Journal of Pest Science 86: 85-90. 
Lane MC. 1941. Wireworms and their control on irrigated lands. USDA Farmers Bulletin 1866: 1-25.

Rabb RL. 1963. Biology of in the Piedmont section of North Carolina (Coleoptera: Elateridae). Annals of the Entomological Society of America 56: 669-676.

Reddy GVP, Tangtrakulwanich K, Wu S, Miller JH, Ophus VL, Prewett J, Jaronski ST. 2014. Evaluation of the effectiveness of the entomopathogens for the management of wireworms (Coleoptera: Elateridae) on spring wheat. Journal of Invertebrate Pathology 120: 43-49.

Seal DR. 1990. The biology of wireworms affecting sweet potatoes in Georgia. Ph.D. dissertation, Department of Entomology, University of Georgia, Athens. 220p.

Seal DR. 1991. Distribution and density of wireworms and their damage in relation to different cultivars of sweet potato. Proceedings of Florida State Horticultural Society 104: 284-286.

Seal DR, Chalfant RB, Hall MR. 1992a. Effectiveness of different seed baits and baiting methods for wireworms (Coleoptera: Elateridae) in sweet potato. Environmental Entomology 21: 957-963.

Seal DR, Chalfant RB, Hall MR. 1992b. Effects of cultural practices and rotational crops on abundance of wireworms (Coleoptera: Elateridae) affecting sweet potato in Georgia. Environmental Entomology 21: 969-974.

Seal DR, McSorely R, Chalfant RB. 1992c. Seasonal abundance and spatial distribution of wireworms (Coleoptera: Elateridae) in Georgia sweet potato fields. Journal of Economic Entomology 85: 1802-1808.

Stone MW. 1975. Distribution of four introduced species in California (Coleoptera: Elateridae). The Coleopterists Bulletin 29: 163-166.

Stone MW. 1980. Notes on the life history of three species of wireworms in California (Coleoptera: Elateridae).

Pan-Pacific Entomologist 56: 157-160. 